\title{
Electrooxidation of new synthetic cannabinoids: Voltammetric determination of drugs in seized street samples and artificial saliva
}

\author{
Marina Dronova, Evgeny Smolianitski, Ovadia Lev*
}

The Casali Center of Applied Chemistry, The Institute of Chemistry, The Hebrew University of Jerusalem, Jerusalem 9190401, Israel

\section{Supporting Information}

Table of contents

$\begin{array}{ll}\text { Data for synthetic cannabinoid standards } & \text { S2 }\end{array}$

Table of ingredients of artificial saliva $\quad$ S3

Cyclic voltammograms of SCs (1-6) having N-alkylindole functionality $\quad$ S4

Cyclic voltammograms of SCs (7-11) having N-alkylindazole functionality S5 $\begin{array}{ll}\text { Cyclic voltammograms of } \mathbf{6} \text { at different scan rates } & \text { S6 }\end{array}$ $\begin{array}{ll}\text { Cyclic voltammograms of } \mathbf{1 1} \text { at different scan rates } & \text { S7 }\end{array}$

Representative GC-MS chromatograms of acetonitrile extracts of seized smoking mixtures

S8

Data for synthetic cannabinoid detection by GC -MS and

LC -MS techniques

S9 
Table S1. Data for synthetic cannabinoid standards, their trivial name, formal name, molecular formula and exact mass (monoisotopic).

\begin{tabular}{|c|c|c|c|}
\hline Trivial name & Formal name & $\begin{array}{l}\text { Molecular } \\
\text { formula }\end{array}$ & $\begin{array}{c}\text { Monoisotopic } \\
\text { mass / Da }\end{array}$ \\
\hline AB-FUBINACA & $\begin{array}{l}\mathrm{N}-[(1 \mathrm{~S})-1-(\text { aminocarbonyl)-2- } \\
\text { methylpropyl]-1-[(4- } \\
\text { fluorophenyl)methyl]-1H-indazole-3- } \\
\text { carboxamide }\end{array}$ & $\mathrm{C}_{20} \mathrm{H}_{21} \mathrm{FN}_{4} \mathrm{O}_{2}$ & 368.1648 \\
\hline AB-CHMINACA & $\begin{array}{l}\mathrm{N}-[(1 \mathrm{~S})-1-(\text { aminocarbonyl)-2- } \\
\text { methylpropyl]-1-(cyclohexylmethyl)- } \\
\text { 1H-indazole-3-carboxamide }\end{array}$ & $\mathrm{C}_{20} \mathrm{H}_{28} \mathrm{~N}_{4} \mathrm{O}_{2}$ & 356.2212 \\
\hline AB-PINACA & $\begin{array}{l}\text { (S)-N-(1-amino-3-methyl-1-oxobutan- } \\
\text { 2-yl)-1-pentyl-1H-indazole-3- } \\
\text { carboxamide }\end{array}$ & $\mathrm{C}_{18} \mathrm{H}_{26} \mathrm{~N}_{4} \mathrm{O}_{2}$ & 330.2056 \\
\hline 5F-AMB & $\begin{array}{l}\text { N-[[1-(5-fluoropentyl)-1H-indazol-3- } \\
\text { yl]carbonyl]-L-valine, methyl ester }\end{array}$ & $\mathrm{C}_{19} \mathrm{H}_{26} \mathrm{FN}_{3} \mathrm{O}_{3}$ & 363.1958 \\
\hline THJ-2201 & $\begin{array}{l}\text { [1-(5-fluoropentyl)-1H-indazol-3-yl]-1- } \\
\text { naphthalenyl-methanone }\end{array}$ & $\mathrm{C}_{23} \mathrm{H}_{21} \mathrm{FN}_{2} \mathrm{O}$ & 360.1638 \\
\hline FDU-PB-22 & $\begin{array}{l}\text { naphthalen-1-yl 1-(4-fluorobenzyl)-1H- } \\
\text { indole-3-carboxylate }\end{array}$ & $\mathrm{C}_{26} \mathrm{H}_{18} \mathrm{FNO}_{2}$ & 395.1321 \\
\hline FUB-PB-22 & $\begin{array}{l}\text { 1-[(4-fluorophenyl)methyl]-1H-indole- } \\
\text { 3-carboxylic acid, 8-quinolinyl ester }\end{array}$ & $\mathrm{C}_{25} \mathrm{H}_{17} \mathrm{FN}_{2} \mathrm{O}_{2}$ & 396.1274 \\
\hline $5 F-P B-22$ & $\begin{array}{l}\text { 1-(5-fluoropentyl)-8-quinolinyl ester- } \\
\text { 1H-indole-3-carboxylic acid }\end{array}$ & $\mathrm{C}_{23} \mathrm{H}_{21} \mathrm{FN}_{2} \mathrm{O}_{2}$ & 376.1587 \\
\hline XLR-11 & $\begin{array}{l}\text { (1-(5-fluoropentyl)-1H-indol-3- } \\
\text { yl)(2,2,3,3- } \\
\text { tetramethylcyclopropyl)methanone }\end{array}$ & $\mathrm{C}_{21} \mathrm{H}_{28} \mathrm{FNO}$ & 329.2155 \\
\hline AM-2201 & $\begin{array}{l}\text { [1-(5-fluoropentyl)-1H-indol-3-yl]-1- } \\
\text { naphthalenyl-methanone }\end{array}$ & $\mathrm{C}_{24} \mathrm{H}_{22} \mathrm{FNO}$ & 359.1685 \\
\hline JWH-018 & $\begin{array}{l}\text { (1-pentyl-1H-indol-3-yl)-1- } \\
\text { naphthalenyl-methanone }\end{array}$ & $\mathrm{C}_{24} \mathrm{H}_{23} \mathrm{NO}$ & 341.178 \\
\hline
\end{tabular}


Table S2. Artificial saliva, table of ingredients.

\begin{tabular}{ll}
\hline Sodium hydrogen carbonate & $4.2 \mathrm{~g}$ \\
Sodium chloride & $0.5 \mathrm{~g}$ \\
Potassium carbonate & $0.2 \mathrm{~g}$ \\
Sodium nitrite & $30 \mathrm{mg}$ \\
\hline
\end{tabular}

Artificial saliva was prepared according to [1]. In brief, ingredients of artificial saliva were dissolved in water and diluted to $900 \mathrm{~mL}$ with water. $\mathrm{pH}$ was adjusted to 5 by adding dilute nitric acid or sodium hydroxide solutions drop by drop, and then the solution was transferred to a $1 \mathrm{~L}$ volumetric flask and diluted to the mark with water.

[1] British Standard "Child use and care articles - Methods for determining the release of NNitrosamines and N-Nitrosatable substances from elastomer or rubber teats and soothers" The European standard EN 12868:1999. Pages 3-15. 

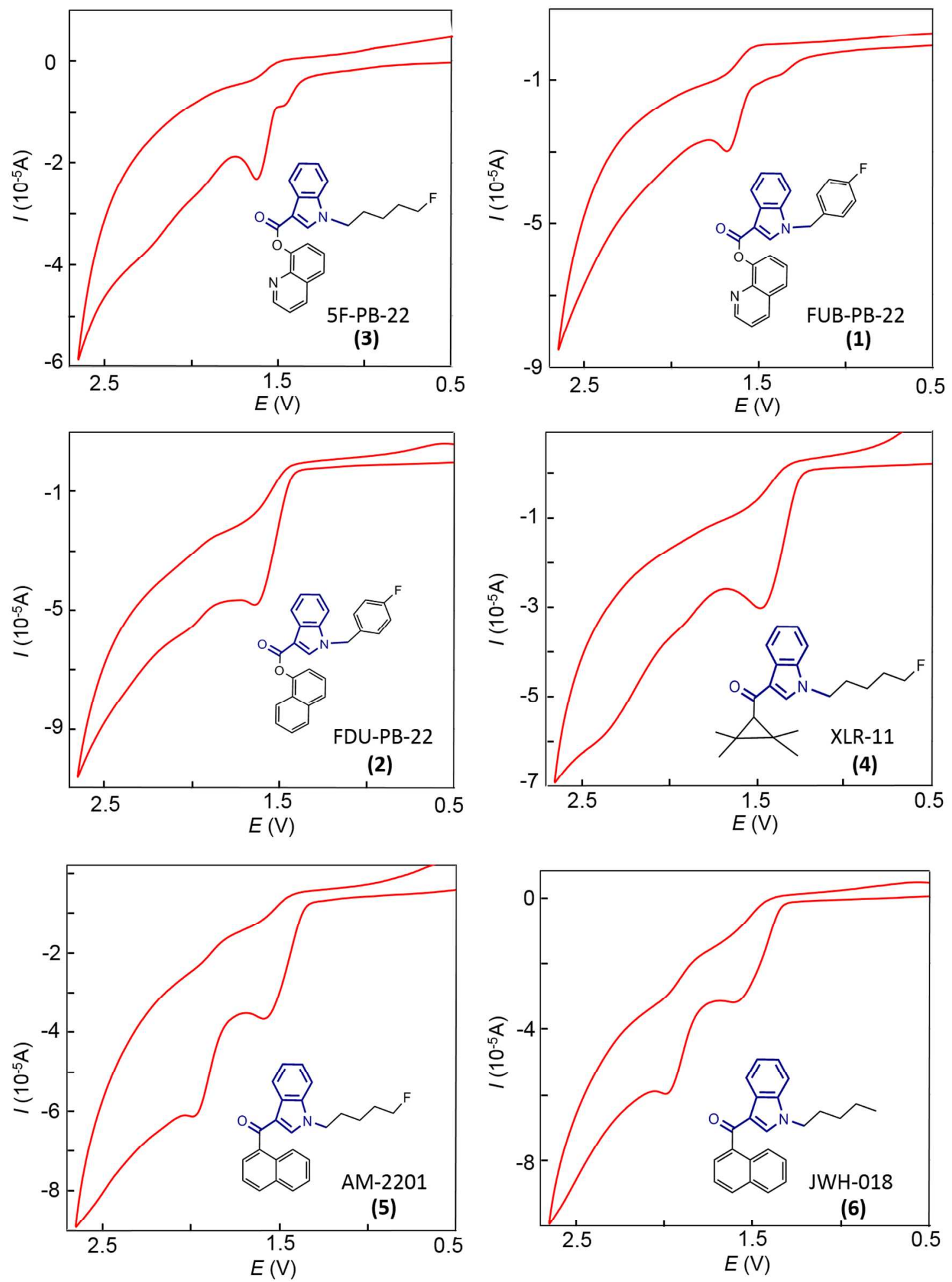

Figure S1. Cyclic voltammograms of SCs having N-alkylindole functionality (1-6), recorded at Pt electrode in $0.01 \mathrm{M} \mathrm{TBAP} / \mathrm{CH}_{3} \mathrm{CN}$ solution for $1 \mathrm{mM}$ concentration of analyte. Scan rate 100 $\mathrm{mVs}^{-1}$ (vs Ag/ $\mathrm{Ag}^{+}$). 

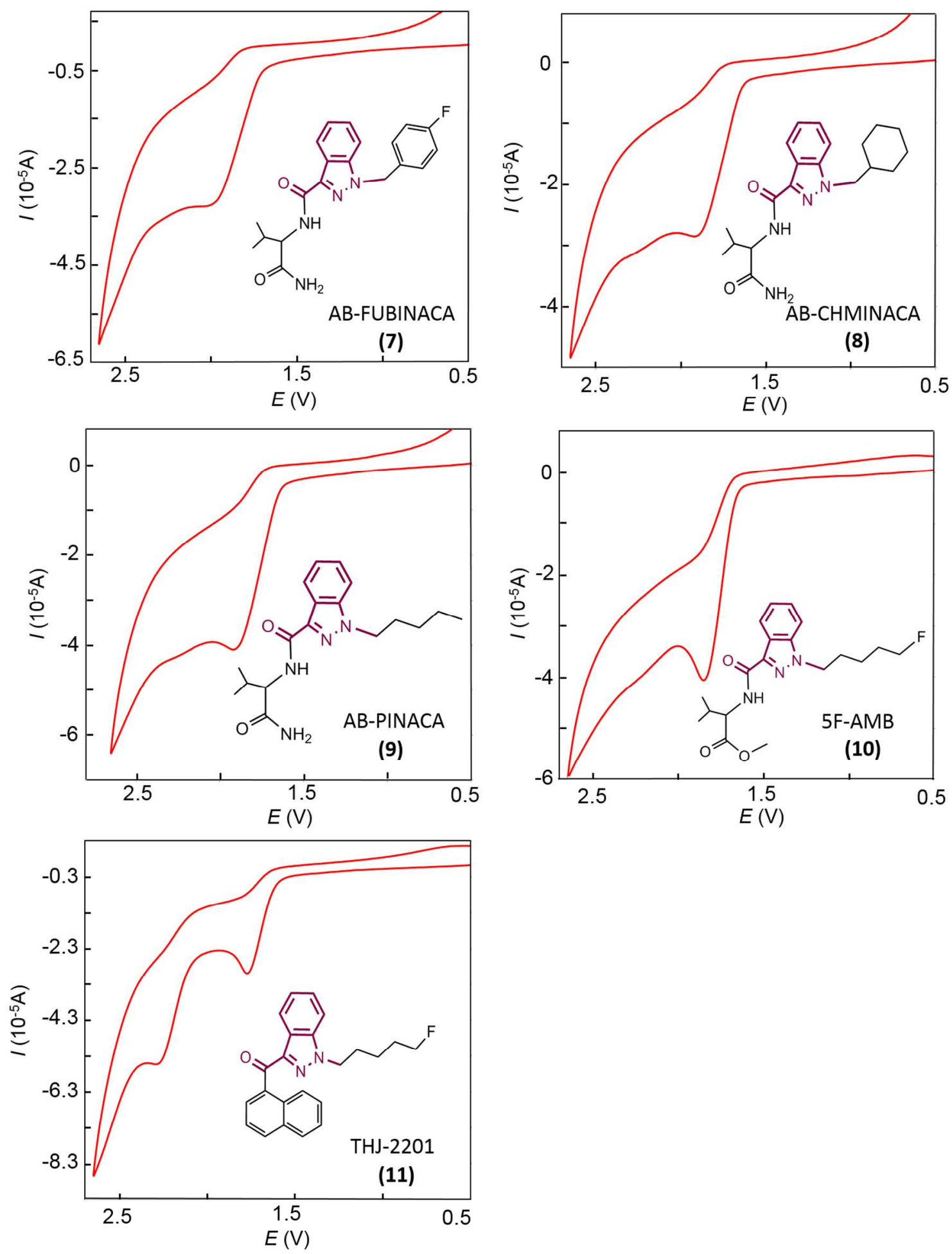

Figure S2. Cyclic voltammograms of SCs having N-alkylindazole fubnctionality (7-11), recorded at Pt electrode in $0.01 \mathrm{M} \mathrm{TBAP} / \mathrm{CH}_{3} \mathrm{CN}$ solution for $1 \mathrm{mM}$ of analytes. Scan rate 100 $\mathrm{mVs}^{-1}$ (vs Ag/ $\mathrm{Ag}^{+}$). 


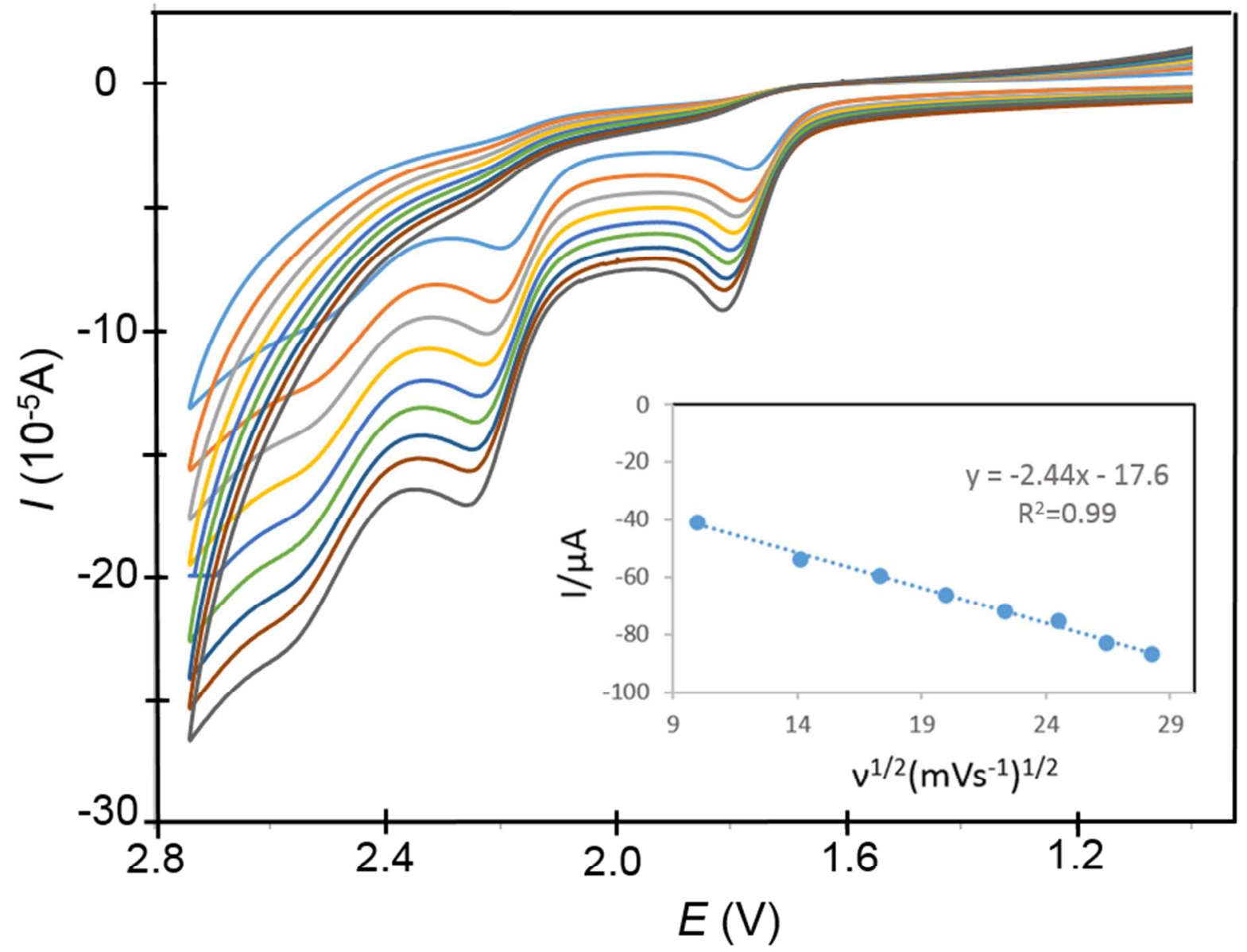

Figure S3. Cyclic voltammograms of $1 \mathrm{mM}$ solution of THJ-2201 (11) in $0.01 \mathrm{M} \mathrm{TBAP} / \mathrm{CH}_{3} \mathrm{CN}$ solution using Pt electrode at different scan rates, $v\left(100,200,300,400,500,600,700,800 \mathrm{mVs}^{-}\right.$ $\left.{ }^{1}\right)$. Insert shows the linear relationship between $I$ and $v^{1 / 2}$. 


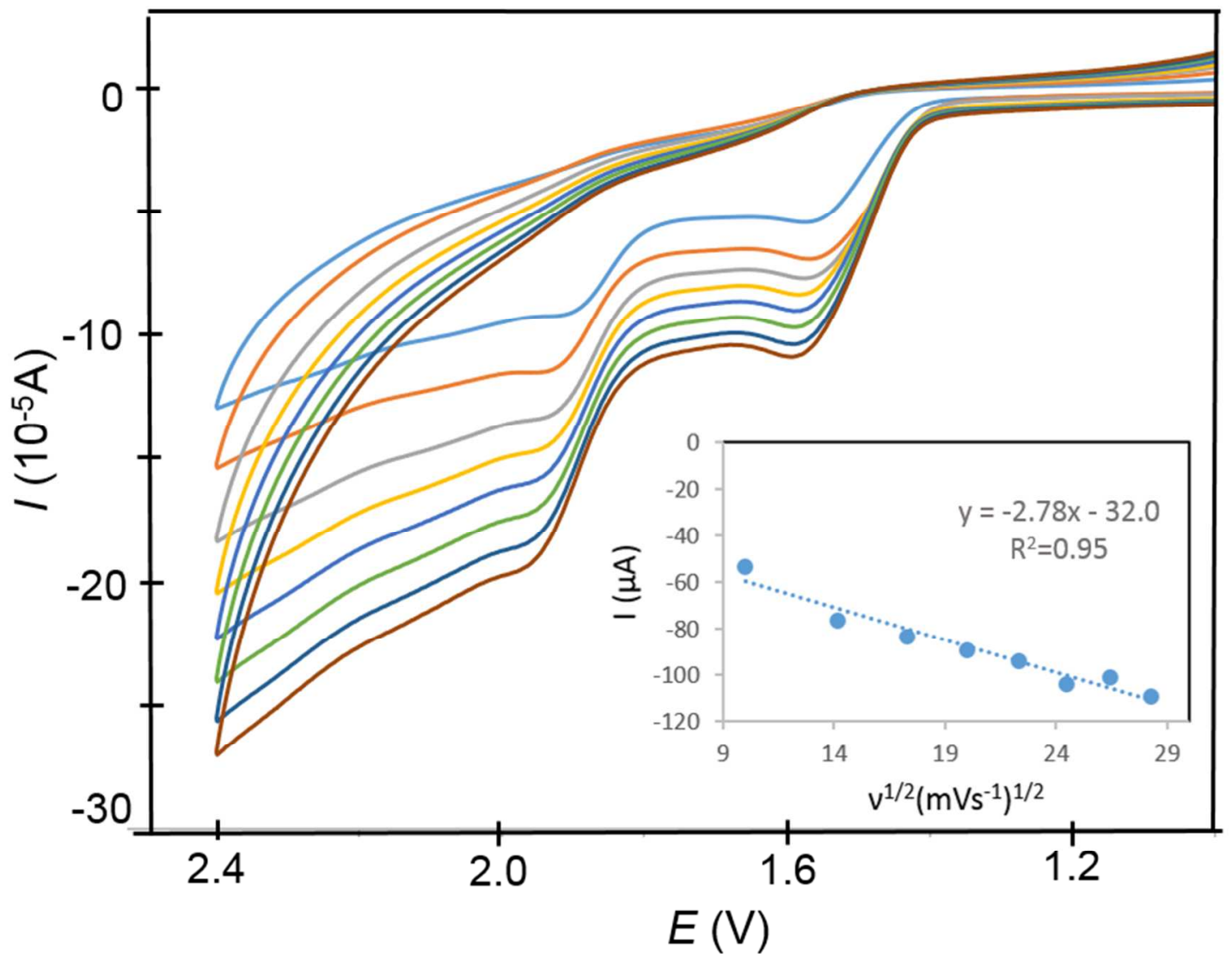

Figure S4. Cyclic voltammograms of $1 \mathrm{mM}$ solution of AM-2201 (6) in $0.01 \mathrm{M} \mathrm{TBAP} / \mathrm{CH}_{3} \mathrm{CN}$ solution, using Pt electrode at different scan rates $v\left(100,200,300,400,500,600,700,800 \mathrm{mVs}^{-}\right.$ $\left.{ }^{1}\right)$. Insert shows the linear relationship between $I$ and $v^{1 / 2}$. 

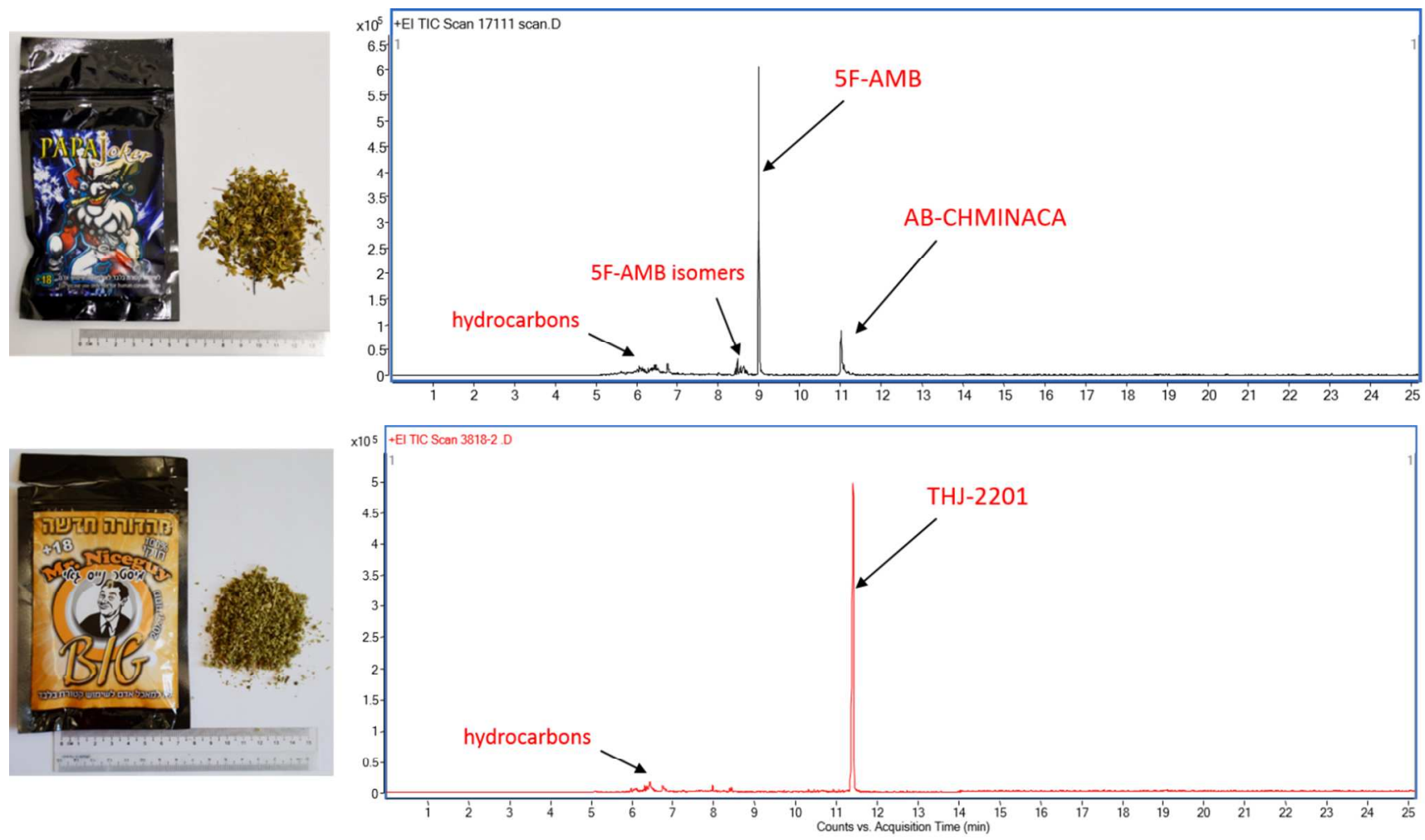

Figure S5. A picture of a seized smoking mixture containing plant material which was suspected to be impregnated with synthetic cannabinoids (left) and the corresponding chromatogram by GC-SMB-QQQ-MS of acetonitrile extract of plant material (right). The mass spectrometer was operated in full scan mode obtaining a total ion chromatogram over a scan range of 45-500 Da. 
Mass spectrometry studies

LC-ESI-QTOF-MS

The analysis was performed using an Agilent 6520 high resolution Quadrupole Time of Flight (QTOF) mass spectrometer with positive electrospray ionization ion source. Analyte separation was conducted with Agilent ZORBAX Eclipse Plus C18 (2.1 x 100 mm, $3.5 \mu \mathrm{m})$. Column temperature was set to $25{ }^{\circ} \mathrm{C}$. The mobile phase consisted of $10 \% \mathrm{MeOH}$ and $90 \% \mathrm{H}_{2} \mathrm{O}$ with $0.1 \% \mathrm{HCOOH}$. The gradient conditions for the mobile phase were as follows: Initial conditions, $10 \% \mathrm{MeOH}$ fed at $0.2 \mathrm{~mL} / \mathrm{min}$ for $1 \mathrm{~min}$. From 1 to $7 \mathrm{~min}$ the composition was ramped to $100 \% \mathrm{MeOH}$, and remained so until $\mathrm{t}=14 \mathrm{~min}$. Finally, at $\mathrm{t}=14.1 \mathrm{~min}$ the composition of the eluent was changed gradually to the initial conditions of $10 \% \mathrm{MeOH}$ and remained so until $\mathrm{t}=23 \mathrm{~min}$. Injection volume was $15 \mu \mathrm{L}$. The mobile-phase flow rate was 0.2 $\mathrm{mL} / \mathrm{min}$. Nebuliser pressure was set to $45 \mathrm{psi}$, drying gas flow was $10 \mathrm{~L} / \mathrm{min}$, drying gas temperature was $300{ }^{\circ} \mathrm{C}$, capillary voltage potential was $4000 \mathrm{~V}$. The fragmentor voltage was set at $100 \mathrm{~V}$, and skimmer voltage was $65 \mathrm{~V}$. Scan range was $100-1700 \mathrm{~m} / \mathrm{z}$. All other MS parameters remained at auto tune conditions.

\section{GC-SMB-EI-QQQ-MS}

The analysis was conducted on an Agilent 7890A GC system coupled to an Agilent 7000A Triple Quadruple Mass Spectrometer (QQQ-MS) equipped with 5975 SMB ion source and interface (Aviv Analytical, Hod Hasharon Israel). The GC column was a $25 \mathrm{~m}$ DB-5MS (Agilent J\&W) capillary column $(0.25 \mathrm{~mm} \times 0.25 \mu \mathrm{m})$. Helium was used as a carrier gas and the flow rate was kept constant at $1.5 \mathrm{~mL} / \mathrm{min}$. The inlet was operated in pulsed splitless mode (40 psi) and kept at $240{ }^{\circ} \mathrm{C}$. Samples of $2 \mu \mathrm{L}$ were injected via automatic liquid sampler. Two sets of thermal gradients were used at the GC oven depending on the nature of the analyte: A) An initial temperature of $70^{\circ} \mathrm{C}$ was held for $0.5 \mathrm{~min}$, and then the temperature was ramped at $30{ }^{\circ} \mathrm{C} / \mathrm{min}$ to $300{ }^{\circ} \mathrm{C}$ and held constant for $6 \mathrm{~min}$. B) An initial temperature of $240{ }^{\circ} \mathrm{C}$ was held for $1 \mathrm{~min}$ and then ramped at $30{ }^{\circ} \mathrm{C} / \mathrm{min}$ to $300{ }^{\circ} \mathrm{C}$ and held constant for $10 \mathrm{~min}$. The quadrupole mass spectrometer was operated in selected ion monitoring mode (SIM). The quantifier and qualifier ions for each analyte are detailed below in Table S3. 
Table S3. Data for synthetic cannabinoid detection by GC-SMB-QQQ-MS and LC-ESI-QTOFMS techniques: major ions, retention time (r.t.); limits of detection (LOD).

\begin{tabular}{|c|c|c|c|c|c|c|}
\hline \multirow{2}{*}{$\begin{array}{c}\text { Synthetic } \\
\text { cannabinoid }\end{array}$} & \multicolumn{3}{|c|}{ GC-SMB-QQQ-MS } & \multicolumn{3}{|c|}{ LC-ESI-QTOF-MS } \\
\hline & $\begin{array}{l}\text { Major ions } \\
\mathrm{m} / \mathrm{z}\end{array}$ & $\begin{array}{l}\text { r.t. } \\
\text { min }\end{array}$ & $\begin{array}{l}\mathrm{LOD} \\
\mathrm{mg} / \mathrm{L}\end{array}$ & $\begin{array}{c}{[\mathrm{M}+\mathrm{H}]^{+}} \\
\mathrm{m} / \mathrm{z}\end{array}$ & $\begin{array}{l}\text { r.t. } \\
\text { min }\end{array}$ & $\begin{array}{l}\mathrm{LOD} \\
\mathrm{mg} / \mathrm{L}\end{array}$ \\
\hline $\begin{array}{c}\text { AB- } \\
\text { FUBINACA }\end{array}$ & $\begin{array}{l}\mathbf{1 0 9}, 253, \\
324,368\end{array}$ & $11.12^{b}$ & 0.275 & 369.1720 & 15.70 & 0.008 \\
\hline $\begin{array}{c}\text { AB- } \\
\text { CHMINACA }\end{array}$ & $\begin{array}{c}\mathbf{2 4 1}, 312, \\
145,356\end{array}$ & $11.02^{\mathrm{a}}$ & 0.440 & 357.2293 & 17.32 & 0.011 \\
\hline AB-PINACA & $\begin{array}{l}\mathbf{2 1 5}, 286, \\
145,330\end{array}$ & $9.43^{\mathrm{a}}$ & 0.045 & 331.2138 & 16.53 & 0.002 \\
\hline 5F-AMB & $\begin{array}{c}\mathbf{2 3 3}, \\
304,145,363\end{array}$ & $8.99^{a}$ & 0.356 & 364.2033 & 18.17 & 0.007 \\
\hline THJ-2201 & $\begin{array}{c}\mathbf{1 2 7}, 360 \\
155,271\end{array}$ & $11.37^{\mathrm{a}}$ & 1.06 & 361.1710 & 19.8 & 0.296 \\
\hline FDU-PB-22 & $\begin{array}{c}\text { 109, 252, } \\
395\end{array}$ & $12.54^{\mathrm{b}}$ & 0.035 & 396.1400 & 20.39 & 0.124 \\
\hline FUB-PB-22 & $\begin{array}{l}\text { 109, 252, } \\
396,207\end{array}$ & $13.42^{b}$ & 0.025 & 397.1356 & 18.64 & 0.002 \\
\hline 5F-PB-22 & $\begin{array}{c}232,144, \\
116,376\end{array}$ & $9.82^{b}$ & 0.009 & 377.1670 & 18.36 & 0.001 \\
\hline XLR-11 & $\begin{array}{c}\text { 232, } 247 \\
144,314 \\
329\end{array}$ & $8.78^{\mathrm{a}}$ & 0.324 & 330.2236 & 20.11 & 0.001 \\
\hline AM-2201 & $\begin{array}{l}\mathbf{2 8 4}, 359, \\
232,127\end{array}$ & $13.00^{\mathrm{a}}$ & 0.622 & 360.1765 & 19.20 & 0.009 \\
\hline JWH-018 & $\begin{array}{l}\mathbf{2 8 4}, 341, \\
214,127\end{array}$ & $11.96^{\mathrm{a}}$ & 0.486 & 342.1854 & 20.62 & 0.005 \\
\hline
\end{tabular}

Quantifying ions (which were always the base peaks) are given in bold and the qualifiers are not emphasized. LOD was calculated as $3 \sigma / \mathrm{S}$; where $\sigma$ is the standard deviation of the background noise, $\mathrm{S}$ is the slope of the corresponding calibration curve. Calibration range for analytes: 0.5 , 1.0, 2.5, 5.0 and $10.0 \mathrm{mg} / \mathrm{L}$. a - Run with GC thermal gradient A (see experimental part). b - Run with GC thermal gradient B (see experimental part). 